\title{
Peran Serta Masyarakat dalam Proses Penyusunan Analisis Mengenai Dampak Lingkungan Hidup
}

\author{
Yurike Inna Rohmawati Ciptaningrum \\ Fakultas Hukum Universitas Jember \\ yurikeinna@gmail.com
}

\author{
Warah Atikah \\ Fakultas Hukum Universitas Jember \\ arah_fhunej@yahoo.co.id \\ Nurul Laili Fadhilah \\ Fakultas Hukum Universitas Jember \\ nulifadh@gmail.com
}

\begin{abstract}
Environmental Impact Analysis or called EIA is a preventive measure to prevent environmental damage as well as a prerequisite for get environmental license. The EIA in its preparation should involve the society, but there are still many societies that have not been fully involved by investors/business actors and the government. Whereas the society has the right and obligation to keep environment. The writen uses normative juridical methods in addressing issues related to guarantees of protection concerning society involvement in the process of preparing to EIA and the legal consequences of non-involvement of the society. Discussion results show that society involvement in the EIA compilation process has been protected and guaranteed its rights by regulation but the implications of the regulation are still minimal. Consequently, the involvement of the public with the implications of EIA documents may be submitted to the Administrative Court and investors/business actors shall be required to improve the phase of the non-involvement of the society in the process of preparing the EIA in accordance with the court's verdict.
\end{abstract}

KEYWORDS: Social Participation, Society, Environmetal Impact Analysis, Administrative Court.

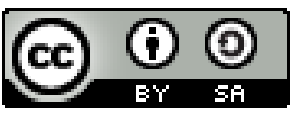

Copyright $\odot 2017$ by Author(s)

This work is licensed under a Creative Commons Attribution-ShareAlike 4.0 International License. All writings published in this journal are personal views of the authors and do not represent the views of this journal and the author's affiliated institutions.

\section{HOW TO CITE:}

Ciptaningrum, Yurike Inna Rohmawati, Warah Atikah \& Nurul Laili Fadhilah. "Peran Serta Masyarakat dalam Proses Penyusunan Analisis Mengenai Dampak Lingkungan Hidup" (2017) 4:1 Lentera Hukum 63-80. 


\section{PENDAHULUAN}

Lingkungan merupakan hal yang sangat krusial di dalam kehidupan. Lingkungan menentukan kehidupan manusia dan makhluk hidup lainnya, namun sebaliknya manusia pun juga dapat menentukan keadaan lingkungan. Di dalam pengelolaan lingkungan berasaskan pelestarian kemampuan agar hubungan manusia dengan lingkungannya selalu berada pada kondisi optimum, dalam arti manusia dapat memanfaatkan sumberdaya dengan dilakukan secara terkendali dan lingkungannya mampu menciptakan sumbernya untuk dibudidayakan. ${ }^{1}$ Istilah "lingkungan" atau bentuk kepanjangannya "lingkungan hidup" itu dengan serta terjemahannya dalam Bahasa Inggris "Environtment", dalam Bahasa Perancis "I'evironnement", dalam Bahasa Jerman "Umwelt", dalam Bahasa Belanda "Milieu”, dalam Bahasa Malaysia "Alam Sekitar", dan dalam Bahasa Tagalog "Kepaligiran", serta dalam Bahasan Thai "Sin-vat-lom". ${ }^{2}$ Untuk menjaga dan mengawasi lingkungan, negara mengatur berbagai aspek lingkungan melalui kebijakan-kebijakan dan regulasi hukum lingkungan guna mencapai keselarasan hubungan antara manusian dan lingkungan hidup. ${ }^{3}$

Definisi hukum lingkungan sendiri secara harfiah dalam literatur Bahasa Inggris yaitu environmental law, di dalam Bahasa Belanda disebut dengan milieurecht, sedangkan di Jerman hukum lingkungan disebut dengan umweltrecht, Perancis menyebutnya dengan droit de environmental, dan hukum lingkungan di Malaysia dalam Bahasa Melayu disebut dengan hukum alam sekitar. ${ }^{4}$ Hukum lingkungan memberikan dasar bagi kebijakan pemerintah dan tindakan untuk melestarikan lingkungan dan untuk menjamin bahwa penggunaan sumber daya alam dilakukan secara patut dan berkelanjutan. ${ }^{5}$

Kegunaan sumber daya alam dan kelestarian lingkungan tergantung pada manusianya. Apabila manusia (masyarakat) menggunakan sesuai dengan porsinya maka lingkungan akan tetap terjaga dan lestari. Sehingga disini masyarakat memiliki peran serta dalam menjaga lingkungan, terkhusus jika terdapat kegiatan/usaha yang berdampak penting, seperti penyusunan Analisis Mengenai Dampak Lingkungan Hidup (AMDAL), karena tidak semua masyarakat terlibat dalam penyusunan AMDAL.

Peran serta masyarakat untuk menyusun dokumen AMDAL dapat menggunakan teori demokrasi deliberatif. Kata "deliberasi" berasal dari kata latin deliberatio yang artinya konsultasi, menimbang-nimbang, atau musyawarah. ${ }^{6}$ Demokrasi bersifat deliberatif, jika proses pemberian alasan atas suatu kandidat kebijakan publik diuji lebih dahulu lewat konsultasi publik atau "diskursus publik". ${ }^{7}$ Demokrasi deliberatif

\footnotetext{
Andi Hamzah, Penegakan Hukum Lingkungan ( Jakarta: Sinar Grafika, 2005) hlm. 3.

St. Munadjat Danusaputro, Hukum Lingkungan Buku I: Umum, (Bandung: Binacipta, 1985) hlm. 62.

3 Mohammad Taufik Makarao, Aspek-Aspek Hukum Lingkungan (Jakarta: PT Ikrar Mandiriabadi, 2006), hlm. 11.

4 Andi Hamzah, supra note $1 \mathrm{hlm} .7$.

5 A'an Efendi, Hukum Lingkungan Instrumen Ekonomik dan Pengelolaan Lingkungan di Indonesia dan Perbandingan dengan Beberapa Negara (Bandung: PT Citra Aditya Bakti, 2014) hlm. 17.

6 Antun Mardiyanta, "Kebijakan Publik Deliberatif: Relevansi dan Tantangan Implementasinya" (2011) 24:3 Jur Univ Airlangga hlm. 269.
}

7 Ibid. 
mengutamakan penggunaan tata cara pengambilan keputusan yang menekankan musyawarah dan penggalian masalah melalui dialog dan tukar pengalaman diantara parapihak dan warga negara. 8 Tujuannya untuk mencapai mufakat melalui musyawarah berdasarkan hasil-hasil diskusi dengan mempertimbangkan berbagai kriteria. Sehingga teori demokrasi deliberatif adalah lebih mengutamakan antar-ide dan antar-pihak. ${ }^{9}$

Peran serta masyarakat lainnya dapat berupa proses pengambilan keputusan administratif. Menurut Lothar Gundli, masyarakat dapat berperan serta dalam pengambilan keputusan administratif melalui: ${ }^{10}$ (i) berbagai bentuk prosedur administratif, seperti analisis mengenai dampak lingkungan, prosedur dan perencanaan perizinan, (ii) pemberian informasi kepada masyarakat. Keterlibatan masyarakat sebagai upaya agar investor/pelaku usaha mendapatkan masukan dari para masyarakat terkait semua yang bersangkutan dengan masyarakat dan lingkungan tersebut. Guna mencapai sasaran tersebut, maka ada hal yang harus dipenuhi. Pertama, adanya komunikasi dua arah yang terus menerus; kedua, informasi yang terkait dengan proyek, program, atau kebijaksanaan disampaikan dengan bermacam-macam teknik yang tidak pasif dan formal tetapi juga aktif dan informal. ${ }^{\text {ll }}$

Akan tetapi, ada dua faktor yang menghambat untuk meningkatkan keterlibatan masyarakat, yakni faktor sosial dan budaya. Dilihat dari sisi sosiologi, rendahnya tingkat pendidikan dan keterbatasan akses informasi akan mempengaruhi tingkat keterlibatan masyarakat. Dalam konteks AMDAL adalah sulit bagi masyarakat untuk memahami informasi yang terkait dengan proyek maupun dengan AMDAL itu sendiri. ${ }^{12}$ Akibatnya, masyarakat akan kesulitan dalam memikirkan dan membayangkan dampak yang akan terjadi.

Dari aspek budaya, dilihat dari pertimbangan pendapat Koentjaraningrat bahwa masih ada konsep yang dominan pada masyarakat Indonesia yakni orientasi keatas. Konsep "orientasi keatas"baik kepada pemimpin formal maupun informal mendorong orang untuk menghindari "perbedaan" pendapat dengan pemerintah maupun pimpinan panutan lainnya. ${ }^{13}$ Di samping kedua faktor di atas, faktor politik juga menjadi kendala bagi tumbuhnya peran serta masyarakat. Para pejabat pemerintah selalu menganggap bahwa masyarakat dianggap belum siap untuk melakukan keterlibatan karena tingkat kesadaran dan pengetahuan masyarakat yang masih rendah.

Dengan demikian, peran serta masyarakat sangat dibutuhkan dalam kegiatan/usaha untuk menyusun dokumen AMDAL. Akan tetapi perlu di kaji lebih lanjut terkait jaminan perlindungan untuk masyarakat yang terlibat dalam proses

\footnotetext{
Ibid hlm. 268.

Ibid.

Mohammad Taufik Makarao, supra note 3 hlm. 54-55.

Sudharto P. Hadi, Aspek-Aspek AMDAL Sejarah, Teori dan Metode, Cetakan Keempat (Yogyakarta: Gadjah Mada University Pers, 2005) hlm. 93.

12 Ibid hlm. 101.

13 Ibid hlm. 101-102.
} 
penyusunan AMDAL dan juga adakah akibat hukum dari tidak dilibatkannya masyarakat dalam proses penyusunan AMDAL.

\section{AMDAL DAN PERMASALAHANNYA}

Indonesia adalah negara yang kaya akan potensi sumber daya alamnya. Indonesia dalam mengelola sumber daya alam (yang disingkat dengan SDA) secara implisit telah diatur dalam konstitusi, khususnya Pasal 33 ayat (3) Undang-Undang Dasar Negara Republik Indonesia Tahun 1945 (UUD 1945). Konstitusi tersebut memberikan mandat agar kekayaan alam Indonesia digunakan untuk kesejahteraan seluruh rakyat Indonesa. Dalam pemanfaatan, pengelolaan lingkungan dan kekayaan alam dapat diwujudkan dengan prinsip pembangunan berkelanjutan dan berwawasan lingkungan. Menurut Surna T. Djajadiningrat, proses pembangunan berkelanjutan bertumpu pada tiga faktor utama, yaitu: (1) kondisi sumber daya alam; (2) kualitas lingkungan, dan (3) faktor kependudukan. ${ }^{14}$ Oleh karena itu, pembangunan berkelanjutan tidak akan bermakna jika tidak memperhatikan aspek-aspek yang berwawasan lingkungan.

Proses pembangunan berkelanjutan dilakukan dengan pemahaman bahwa pembangunan di anggap sebagai sesuatu yang dapat menyelesaikan segala persoalan, yakni kemiskinan, keterbelakangan, dan masalah-masalah sosial ekonomi lainnya. ${ }^{15}$ Sehingga untuk menjalankan pembangunan terdapat keterkaitan dengan perekonomian karena banyak para investor/pelaku usaha baik lokal maupun asing datang ke Indonesia untuk membangun usaha/kegiatan atau pun mengeksplorasi dan mengeksploitasi Sumber Daya Alam (SDA). Hal tersebut dapat dilihat bahwa hampir semua daerah di Indonesia terdapat pabrik, proyek, maupun eksplorasi SDA.

Akan tetapi, segala strategi dan kebijakan yang berkaitan dengan lingkungan memerlukan tafsir konstitusi secara khusus ketika aktor-aktor negara ingin melaksanakan aktivitas perekonomian. ${ }^{16} \mathrm{Hal}$ ini harus benar-benar dipahami untuk mencegah terjadinya dampak negatif atas kerusakan alam dan lingkungan. Dengan demikian, Investor/pelaku usaha yang akan mendirikan ataupun membangun kegiatan/usaha harus memiliki surat izin lingkungan karena nantinya izin lingkungan menjadi prasyarat untuk mendapatkan izin usaha/kegiatan. Sebagai instrumen hukum administrasi, pemberian izin merupakan awal proses pengendalian hukum yang hanya mungkin dapat berlaku efektif, ketika diikuti adanya pengawasan yang proposional dan ketat oleh pemerintah sebagai aparat penegak hukum untuk menjamin bahwa pemegang izin telah dan akan tetap melaksanakan isi yang tertuang dalam izin secara konsisten. ${ }^{17}$ Perizinan lingkungan hidup sebagai suatu sistem UUPPLH juga terkait

14 Pan Mohamad Faiz, "Perlindungan terhadap Lingkunngan dalam Perspektif Konstitusi" (2016) 13:4 Jurnal Konstitusi hlm. 773.

15 N.H.T. Siahaan, Hukum Lingkungan dan Ekologi Pembangunan, Cetakan Kedua (Jakarta: Erlangga 2004) hlm. 56.

16 Pan Mohamad Faiz, supra note $12 \mathrm{hlm} .774$.

17 T. Gayus Lumbun, Hukum dan Lingkungan Hidup di Indonesia (Jakarta: Program Pasca Sarjana Fakultas Hukum Universitas Indonesia, 2001) hlm. 499-500. 
dengan ketentuan tentang penanggulangan dan pemulihan kondisi lingkungan hidup. Penanggulangan maksudnya yaitu kewajiban yang harus dilakukan oleh pemegang izin jika terjadi pencemaran/kerusakan lingkungan. ${ }^{18}$

Syarat untuk mendapatkan izin lingkungan yang berdampak penting yakni harus memiliki AMDAL. Jenis-jenis kegiatan/usaha yang wajjib AMDAL antara lain terdapat beberapa, yakni bidang multisektor, ${ }^{19}$ bidang pertahanan, ${ }^{20}$ bidang pertanian, ${ }^{21}$ dan sebagainya. Regulasi AMDAL dalam kegiatan/usaha sering hanya dijadikan sebagai syarat formalitas bahkan kegiatan/usaha banyak yang tidak memiliki AMDAL, maka banyak AMDAL yang abal-abal atau palsu. Padahal untuk menyusun AMDAL perlu adanya keterlibatan masyarakat dengan tujuan untuk mewujudkan pelaksanaan proses izin lingkungan yang terbuka, efektif, bertanggungjawab, dan berkualitas. Tujuan dilibatkannya masyarakat dalam proses penyusunan AMDAL adalah tiga.

Pertama, masyarakat mendapatkan informasi terkait rencana kegiatan/ usaha yang akan berdampak penting bagi lingkungan. Hal ini disebabkan karena apabila terjadi dampak dari kegiatan/usaha tersebut maka masyarakat yang akan merasakan dampaknya, dan pemberian informasi harus transparan dalam arti tidak boleh ada yang disembunyikan.

Kedua, saran, pendapat, atau tanggapan terkait rencana kegiatan/usaha dapat disampaikan oleh masyarakat melalui lisan atau pun tulisan kepada investor/ pelaku usaha. Dengan adanya saran, pendapat, maupun tanggapan investor/pelaku usaha mendapatkan informasi maupun masukan untuk rencana kegiatan/usaha atau pun lingkungan.

Ketiga, adanya pelibatan masyarakat dalam proses pengambilan keputusan terkait rekomendasi layak atau tidaknya rencana kegiatan/usaha. Pelibatan masyarakat disini sangat penting karena masyarakat yang lebih tahu bagaimana kondisi lingkungan sekitar dan kelayakan dari rencana kegiatan/usaha setelah melalui beberapa prosedur.

Meskipun telah ada regulasi yang mengatur adanya tujuan pelibatan masyarakat dalam proses AMDAL tetapi implementasinya masih banyak masyarakat yang belum diikutsertakan, khususnya masyarakat yang kontra dengan kegiatan/usaha tersebut sehingga menimbulkan banyak permasalahan, juga masih banyak kegiatan/usaha tidak memiliki AMDAL, seperti kasus pembangunan PLTU di Teluk Sepang, Bengkulu, ${ }^{22}$

Helmi, Hukum Perizinan Lingkungan Hidup ( Jakarta: Sinar Grafika, 2012) hlm. 105.

19 Jenis kegiatan multisektor dapat berupa: reklamasi wilayah pesisir/pulau-pilau kecil, pengambilan air bersih dari danau, sungai, mata air, atau sumber air permukaan lainnya, pembangunan bangunan gedung dengann luas lahan $>5 \mathrm{Ha}$, dan sebagainya.

20 Bidang pertahanan dapat berupa: pembangunan pangkalan angkatan laut, angkatan udara, dan angkatan darat.

21 Budidaya tanaman pangan maupun holtikultur dengan luas lahan $>2000 \mathrm{Ha}$ dan $5000 \mathrm{Ha}$, dan sebagainya.

22 Kasus pembangunan PLTU di Teluk Sepang Bengkulu di tolak oleh warga satu kelurahan Teluk Sepang, Kecamatan Kampung Melayu, Kota Bengkulu yang meminta pemerintah provinsi untuk tidak melanjutkan rencana pembangunan PLTU yang akan dibangun dekat dengan Pelabuhan Pulau Baai, karena dampak yang terjadi sangat besar, seperti racun debu, hasil tangkapan nelayan yang akan menurun, rusaknyaterumbu karang, dan kematian dini, dan penyakit yang mematikan. Selain itu sosialisasi pembangunan PLTU tidak sampai ke lapisan masyarakat paling bawah hanya diwakili 
proyek reklamasi Teluk Jakarta, ${ }^{23}$ kasus reklamasi Tanjung Benoa di Bali, ${ }^{24}$ kasus proyek Hambalang, ${ }^{25}$ dan masih banyak lagi kasus-kasus di Indonesia ini yang tidak hanya dilakukan oleh investor/pelaku usaha tetapi juga pemerintah.

Uraian di atas menegaskan bahwa masih banyak masyarakat yang belum dilibatkan dalam proses penyusunan AMDAL. Berangkat dari permasalah ini perlu dikaji lebih lanjut terkait aspek hukum peran serta masyarakat dalam proses penyusunan analisis mengenai dampak lingkungan hidup guna menjamin hak serta kewajiban masyarakat dalam melindungi dan mengelola lingkungan hidup.

\section{PERAN SERTA MASYARAKAT DALAM PROSES PENYUSUNAN ANALISIS MENGENAI DAMPAK LINGKUNGAN HIDUP}

\section{A. Jaminan Perlindungan Keterlibatan Masyarakat dalam Proses Penyusunan AMDAL}

AMDAL merupakan prasyarat bagi investor/pelaku usaha guna mengetahui kemungkinan dampak yang akan terjadi akibat dari rencana pembangunan kegiatan/usaha, seperti kebisingan, banjir, pencemaran limbah, pencemaran udara, perubahan arus, dan sebagainya. Pada hakikatnya dokumen AMDAL dapat memberikan potret yang jelas secara ilmiah tentang analisis kegiatan dan dampak yang mungkin terjadi dari sebuah kegiatan/usaha yang akan dilakukan. Berkaitan dengan hal tersebut posisi AMDAL sangat startegis dalam upaya perlindungan preventif dalam

oleh lurah dan camat, sedangkan penduduk tidak mendapatkan informasi dampak PLTU secara menyeluruh, karena yang di media massa hanya dampak baik dari PLTU. Lihat dan baca https://m.tempo.co/read/news/2016/09/02/173801157/tolak-pltu-warga-satu-kelurahan-di-bengkuluminta-direlokasi. Di akses pada Rabu, 14 Juni 2017, pukul 09.42 WIB.

23 Pemerintah Provinsi Jakarta periode sebelumnya yakni yang sering disapa Ahok diminta untuk membatalkan Peraturan Gubernur (Pergub) tentang reklamasi kawasan strategis pantai utara Jakarta karena menyebabkan banyak masalah dan juga pembuatan pergub tidak melibatkan masyarakat. Selain itu, proyek reklamasi Teluk Jakarta dalam melakukan penyusunan AMDAL tidak melibatkan nelayan. Lihat dan baca http://www.mongabay.co.id/2017/01/17/tanpa-perda-zonasi-ahok-ternyatasudah-terbitkan-pergub-reklamasi/. Di akses pada Rabu, 14 Juni 2017, pukul 08.00 WIB.

24 Reklamasi Teluk Benoa di Bali mendapat kecaman dari banyak masyarakat yang tergabung dalam forbali. Pasalnya terjadi dampak seperti ancaman banjir, 700Ha akan tenggelam,akibat berkurangnya wilayah tampungan banjir dari lima DAS besar, serta dalam konsultasi tidak semua masyarakat dilibatkan, khususnya masyarakat yang terkena dampak seperti kelompok nelayan, Bendesa Adat Kelan, Bendesa Adat Sidakarya dan Kepala Desa Sidakarya, dan desa-desa yang terdekat dengan Teluk Benoa yang menolak reklamasi juga tidak diundang. Bahkan PT. TWBI juga tidak melibatkan masyarakat di Kabupaten Karangasem di dalam konsultasi AMDAL. Lihat dan baca http://www.forbali.org/id/pernyataan-sikap-tolak-reklamasi-berkedok-revitalisasi-teluk-benoa/, di akses pada Rabu, 14 Juni 2017, pukul 08.40 WIB.

25 Proyek Hambalang tidak hanya terkait korupsi saja, akan tetapi banyak terjadinya penyimpangan. BPK mengemukakan bahwa ada empat penyimpangan yakni mulai tahap perencanaan, anggaran kontrak tahun yang tidak memenuhi syarat, dan juga penyimpangan pembayaran. Selain itu, penyimpangan proyek Hambalang juga berdasarkan aspek formal dan aspek teknis. Aspek formalnya tidak ada studi AMDAL terkait pembangunan pusat pelatihan olahraga Hambalang. Lihat dan baca http://www.bpk.go.id/news/bpk-beberkan-empat-tahap-penyimpangan, diakses pada Rabu, 14 Juni 2017, pukul 10.09 WIB. 
perizinan suatu kegiatan berwawasan lingkungan. ${ }^{26}$ Untuk prosedur penyusunan AMDAL dapat dilihat pada diagram di bawah ini: ${ }^{27}$

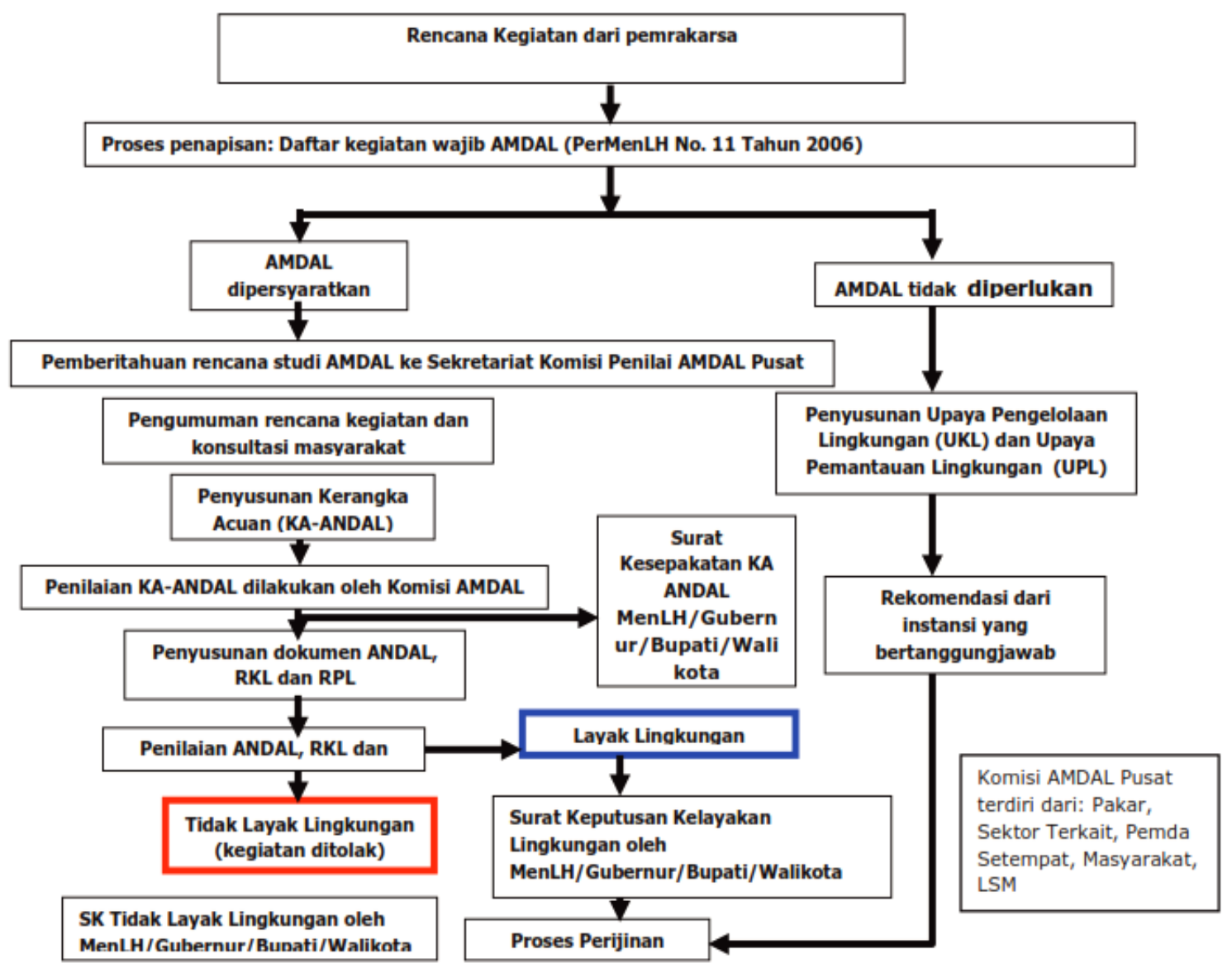

Diagram pada bagian sebelah kiri di atas hanya menjelaskan terkait penyusunan dokumen AMDAL, sehingga dalam penyusunannya terdapat tiga tahap. Tahap tersebut diantaranya adalah kerangka acuan (KA), analisis dampak lingkungan hidup (AMDAL), serta rencana pengelolaan lingkungan hidup-rencana pemantauan lingkungan hidup (RKL-RPL). Tahap untuk menuju KA harus melewati penapisan (screening) dan pelingkupan (scoping). Penapisan bertujuan untuk menetapkan dan memilih kegiatan/usaha mana yang harus memiliki dan dilengkapi AMDAL. Proses penapisan secara berurutan dapat dilakukan melalui pemahaman mengenai kegiatan/usaha yang akan dilakukan mulai dari kegunaannya hingga kreativitasnya, menetapkan dampak negatif yang akan muncul, cara mengurangi maupun menghilangkan dampak, sampai melakukan penilaian dan memutuskan kegiatan/usaha tersebut telah sesuai dengan penapisan. Kemudian untuk pelingkupan agar AMDAL menghasilkan data dan informasi lingkungan yang relevan sesuai dengan rencana

26 Masrudi Muchtar, dkk, Hukum Kesehatan Lingkungan (Kajian Teoritis dan Perkembangan Pemikiran) ( Yogyakarta: Pustaka Baru Press, 2016) hlm. 188.

27 Masri, R.M, "Evaluasi AMDAL Pembangunan Gedung 10 Lantai Di Pusat Kota Bandung" (2016) 14: 2 Jurnal UMM hlm. 193. 
usaha/kegiatan yang bersangkutan. ${ }^{28}$ Dengan kata lain, pelingkupan hanya bertujuan untuk membatasi penelitian AMDAL pada kegiatan-kegiatan yang memiliki dampak penting sesuai dengan kriteria umum atau yang telah diamanatkan pada Pasal 22 ayat (2) Undang-Undang Nomor 32 Tahun 2009 tentang Perlindungan dan Pengelolaan Lingkungan Hidup atau di singkat dengan UUPPLH.

Pada tahap pelingkupan harus diidentifikasi terlebih dahulu pihak-pihak yang berkepentingan, seperti pelaku usaha/investor, pemerintah yang berwenang, dan masyarakat yang telah diamanatkan dalam peraturan perundang-undangan. Pengidentifikasian para pihak yang terlibat khususnya masyarakat dalam memberikan penilaian terhadap rencana kegiatan/usaha dapat melalui proses pengumuman yang dilakukan oleh investor/pelaku usaha melalui papan pengumuman atau media cetak, seperti pamflet, banner, spanduk, dan lain-lain. Pemberian informasi harus menjangkau masyarakat dengan harapan agar mendapatkan informasi yang transparan, lengkap dan harus menggunakan bahasa yang dimengerti oleh masyarakat. Setelah adanya pengumuman mayarakat berhak untuk memberikan saran, pendapat, atau tanggapan secara lisan atau tulisan kepada investor/pelaku usaha dan pemerintah (yakni menteri, gubernur, bupati/walikota) sebagaimana kewenangannya dalam melakukan penilaian AMDAL apabila terdapat ketidak-lengkapan dan tidak adanya transpransi dalam memberikan informasi. Hal tersebut senada dengan isi dari Pasal 26 ayat (2) UUPPLH, Pasal 9 ayat (2) Peraturan Pemerintah Nomor 27 Tahun 2012 tentang Izin Lingkungan, dan lampiran I Peraturan Menteri Lingkungan Hidup Nomor 17 Tahun 2012 tentang Pedoman Keterlibatan Masyarakat dalam Proses Penyusunan Analisis Mengenai Dampak Lingkungan Hidup.

Jangka waktu masyarakat untuk memberikan saran, pendapat, dan tanggapan terkait rencana kegiatan/usaha adalah 10 hari kerja sejak pengumuman tersebut diumumkan. Saran, pendapat, maupun tanggapan yang disampaikan oleh masyarakat digunakan sebagai masukan untuk menyusun KA oleh investor/pelaku usaha. Masyarakat yang menyampaikan saran, pendapat, atau tanggapan dapat berupa informasi deskriptif tentang keadaan lingkungan rencana kegiatan/usaha, nilai-nilai lokal terkait rencana usaha/kegiatan yang diusulkan, dan aspirasi masyarakat tentang rencana kegiatan/usaha. Jika dilihat dari implementasinya jangka waktu yang diberikan sangat singkat karena masyarakat dalam jangka waktu tersebut belum tentu mengetahui pengumumannya. Oleh karenanya, hak masyarakat masih belum digunakan secara optimal dan tepat. Hal tersebut diperkuat dengan Peraturan Pemerintah Nomor 27 Tahun 1999 tentang Analisis Mengenai Dampak Lingkungan Hidup (selanjutnya di singkat PP AMDAL-99). Apabila melihat dari PP AMDAL-99 maka peraturan pemerintah yang terbaru mengalami kemerosotan substansi.

Berdasarkan Pasal 19 ayat (3) PP AMDAL-99 mencantumkan bahwa warga masyarakat yang berkepentingan berhak mengajukan saran, pendapat, dan tanggapan tentang rencana kegiatan/usaha secara tertulis kepada instansi yang bersangkutan dalam jangka waktu 30 hari kerja sejak diumumkan sebelum kepastian tentang 
pemberian izin terhadap rencana kegiatan/usaha yang diberikan. ${ }^{29}$ Dari Pasal 19 ayat (3) PP AMDAL-99 tersebut bila dibandingkan dengan peraturan pemerintah yang terbaru maka jelas terdapat celah bagi investor/pelaku usaha untuk lolos dalam tahap ini.

pelibatan masyarakat sebelum tahap dokumen KA masih kurang efektif karena tidak semua masyarakat mengetahui rencana kegiatan/usaha. Hal itu disebabkan letak papan pengumuman yang kurang strategis sehingga jarang dibaca oleh masyarakat, selain itu juga tidak semua masyarakat membaca media massa dan media elektronik. Dilihat dari sudut pandang pemerintah bahwa dalam menilai kegiatan/usaha dan dampak penting lingkungan juga tidak mudah karena harus memperhatikan bentang alam, perubahan bentuk lahan, eksploitasi sumber daya alamnya, melihat masyarakat yang terkena dampak, luas wilayah yang akan digunakan sebagai proses kegiatan/usaha, dan syarat-syarat yang harus dilengkapi oleh investor/pelaku usaha. Namun, kelemahannya pemerintah jarang memperhatikan perubahan bentang alam di daerah yang akan digunakan untuk kegiatan/usaha sehingga dengan mudah banyak para investor/pelaku usaha yang meremehkan pembuatan penyusunan AMDAL. Hal lain juga karena yang menyetujui persyaratan izin lingkungan berada di provinsi sehingga dokumen izin lingkungan atau AMDAL tidak sesuai dengan kondisi di lapangan, serta tidak sesuai dengan tata ruang dan tata wilayah. Ketika penapisan dan pelingkupan telah dilakukan, selanjutnya menuju ke tahap penyusunan dokumen KA.

Dokumen KA berisi ruang lingkup kajian AMDAL dimana memuat tugas-tugas yang sesuai dengan dampak penting rencana kegiatan/usaha yang dibuat oleh investor/pelaku usaha. Kendatipun demikian, KA secara administrasi telah dinyatakan lengkap maka akan di nilai oleh Komisi Penilai AMDAL. Komisi Penilai AMDAL yang dibentuk oleh pemerintah yang berwenang harus memiliki lisensi dan lulus sertifikasi. Selanjutnya tim teknis ditugaskan oleh Komisi Penilai AMDAL untuk melakukan penilaian KA dengan melibatkan investor/pelaku usaha untuk menyepakati KA.

Hasil penilaian KA yang telah disepakati akan disampaikan kepada Komisi Penilai AMDAL. Jika hasil penelitian dari tim teknis perlu adanya perbaikan, maka dokumen akan disampaikan oleh tim teknis kepada Komisi Penilai AMDAL untuk dikembalikan ke investor/pelaku usaha agar diperbaiki. Sedangkan untuk jangka waktu penilaian sesuai dengan regulasi yaitu 30 hari kerja sejak KA diterima dan dinyatakan lengkap oleh Komisi Penilai AMDAL. Sehingga dikarenakan regulasi telah menyatakan seperti itu, apabila syarat administrasi belum lengkap dan sudah tidak ada perbaikan dokumen lagi maka surat keputusan KA tidak dapat diterbitkan oleh Komisi Penilai AMDAL sesuai dengan hasil penilaian akhir dari tim teknis. Namun, ternyata pihak pemerintah yang telah ditunjuk oleh Komisi Penilai AMDAL untuk memberikan penilaian dan lulus bersertifikat tidak menjamin jika penyusunan KA akan sesuai dengan prosedur. Maksudnya bahwa permasalahan yang penulis maksud terkait dengan keadaan yang sering kali di sengaja oleh para investor/pelaku usaha untuk

29 Daud Silalahi dan Kristanto, Perkembangan Pengaturan AMDAL di Indonesia, (Bandung: Keni Media, 2016) hlm. 62. 
kepentingan keleluasaan bagi pelaksana AMDAL, misal dalam pengukuran kualitas air yang sering tidak disebutkan terkait stasiun pengukurannya, lamanya pengambilan contoh air, bahkan sering tidak disebutkan unsur-unsur yang akan di analisis di laboratorium. ${ }^{30}$ Meskipun terkadang tidak sengaja karena tidak diketahui oleh para pihak. Bila penyusunan dokumen KA telah lengkap dan sesuai dengan prosedur serta regulasi, maka dapat melanjutkan ke tahap penyusunan AMDAL dan RKL-RPL.

AMDAL merupakan tahap untuk menelaah hasil dari penyusunan KA secara cermat dan teliti dengan menggunakan metodologi yang telah disepakati. Telah yang dimaksud adalah peng-evaluasian yang di identifikasi dari dampak penting pada pelingkupan dan KA. Oleh karena itu, penyusunan AMDAL hanya berfokus pada dampak penting dan bertujuan untuk menentukan besaran dampak yang akan timbul.

Dalam menyusun AMDAL terdapat langkah-langkah penting yang harus dilaksanakan oleh penyusun AMDAL, yaitu: ${ }^{31}$ dapat mengumpulkan data dan informasi tentang rencana kegiatan dan rona lingkungan awal. Data yang dimaksud harus sesuai dengan yang tercantum dalam KA AMDAL, kemudian proyeksi perubahan rona lingkungan awal sebagai akibat dari adanya rencana usaha/ kegiatan, penentuan dampak penting terhadap lingkungan akibat rencana kegiatan dan evaluasi dampak penting terhadap lingkungan.

Terkait teknis dalam pengajuan penyusunan AMDAL terlebih dahulu investor/pelaku usaha harus menyusun AMDAL yang nantinya akan diajukan kepada pemerintah yang berwenang sesuai dengan letak kegiatan/usaha tersebut melalui sekretaris Komisi Penilai AMDAL untuk KA yang telah di nilai oleh Komisi Penilai AMDAL pusat, provinsi, maupun kabupaten/kota. Untuk teknis menyusun AMDAL hampir sama dengan menyusun KA yaitu harus melengkapi syarat administrasi terlebih dahulu yang dinilai oleh tim teknis untuk menilai dokumen AMDAL. Lalu hasil penilaian dokumen AMDAL akan disampaikan tim teknis ke tim Komisi Penilai AMDAL.

Teknis selanjutnya yakni besaran dampak yang diketahui akan dinilai oleh tim komisi penilai AMDAL. Setelah itu dilanjutkan ke penentuan sifat penting dampak. Caranya dengan membandingkan antara besaran dampak dengan kriteria dampak penting sesuai dengan apa yang ditetapkan oleh pemerintah. Lalu mengevaluasi keterkaitan antar dampak yang lain.

Komisi Penilai AMDAL dalam mengerjakan tugasnya juga melibatkan masyarakat dimana setelah penyusunan KA selesai, investor/pelaku usaha menyampaikan, menerima dan mendokumentasikan Saran, Pendapat dan Tanggapan (SPT) masyarakat. Adanya SPT diharapkan masyarakat menggunakan haknya untuk menyampaikan SPT secara tertulis maupun lisan terkait rencana kegiatan/usaha yang akan diadakan. Sama seperti yang telah dilakukan ketika pelaksanaan pelingkupan.

30

F. Gunawan Suratmo, Analisis Mengenai Dampak Lingkungan, (Yogyakarta: Gadjah Mada University Pers, 2009) hlm. 71.

31 Masrudi Muchtar, dkk, supra note 20 hlm. 200. 
Bedanya hanya saja dalam melakukan SPT ini investor/pelaku usaha dapat menggunakan konsultasi publik kepada masyarakat. Konsultasi publik ini dapat dengan berbagai cara, metode secara efektif dan efisien untuk menjaring SPT masyarakat. Konsultasi publik dapat dibuat dengan lokakarya, seminar, FGD (Focus Group Discussion), temu warga, forum dengar pendapat, dialog interaktif, maupun menggunakan cara yang lainnya. Dalam konsultasi publik tidak hanya dihadiri masyarakat yang terkena dampak ataupun yang telah diamanatkan dalam regulasi saja tetapi juga tokoh masyarakat dan instansi terkait.

Ketika acara konsultasi publik diadakan investor/pelaku usaha menyampai-kan informasi mengenai tujuan konsultasi publik, waktu dan tempat konsultasi publik, cara atau proses konsultasi publik yang akan dilakukan oleh masyarakat, dimana saja masyarakat dapat memperoleh informasi tambahan, dan lingkup tanggapan dan informasi yang diharapkan oleh masyarakat. ${ }^{32}$ Selain itu, konsultasi publik sebagai cara untuk memilih wakil masyarakat kemudian menetapkannya menjadi perwakilan anggota komisi penilai AMDAL.

Wakil masyarakat yang dipilih dan ditetapkan untuk menjadi anggota Komisi Penilai AMDAL dilakukan berbarengan pelaksanaan konsultasi publik. Wakil masyarakat yang menjadi anggota Komisi Penilai AMDAL ditetapkan berdasarkan proporsi dan mewakili semua aspirasi masyarakat. Dimana hasil ketetapan konsultasi publik dan wakil masyarakat yang terpilih dimasukkan dalam surat kuasa atau surat penetapan yang ditandatangani oleh masyarakat yang hadir dalam konsultasi publik. Kemudian investor/pelaku usaha dapat memberitahukan kepada sekretaris Komisi Penilai AMDAL terkait hasil penetapan wakil masyarakat sesuai dengan kewenangannya.

Wakil masyarakat yang terpilih untuk menjadi anggota Komisi Penilai AMDAL memiliki 2 kewajiban. Pertama, melakukan komunikasi dan konsultasi rutin dengan masyarakat terkena dampak, kedua, menyampaikan aspirasi masyarakat yang terkena dampak dalam rapat Komisi Penilai AMDAL. Sehingga dengan kewajiban itu lah wakil masyarakat harus menjalankan tanggungjawabnya secara benar.

Bercermin dari kewajiban wakil masyarakat tersebut apabila ditarik dalam realita yang ada saat ini yang menjadi wakil selain masyarakat yang terkena dampak yaitu WALHI. Dimana wakil masyarakat yang dipilih harus benar-benar memperjuangkan haknya untuk menjadikan daerahnya lebih baik dan memiliki jiwa sosial yang tinggi. Tetapi terkadang juga ada oknum yang salah menggunakan tanggungjawabnya. Oknum tersebut akan dengan mudah terpengaruh oleh para investor/pelaku usaha yang nakal ingin dengan mudah menyelesaikan penyusunan AMDAL.

Penulis juga melihat bahwa dalam tahap penyusunan ini yang diikutsertakan untuk konsultasi publik maupun SPT adalah masyarakat yang setuju dengan kegiatan/usaha sedangkan untuk masyarakat yang tidak setuju dengan kegiatan/ usaha maka tidak diikutsertakan karena dianggap akan mempersulit para pemrakarsa dalam

Daud Silalahi dan Kristianto, supra note 23 hlm. 284. 
hal ini yaitu investor/pelaku usaha. Sehingga apabila dibiarkan secara terus menerus menyebabkan kesenjangan sosial dan adanya kubu di suatu daerah. Hal ini dapat dilihat di daerah-daerah wilayah Indonesia khususnya pedesaan. Pihak yang setuju dengan kegiatan/usaha biasanya disebabkan akan mendapat keuntungan sedangkan yang tidak setuju disebabkan dengan alasan masyarakat khawatir dengan adanya dampak dari kegiatan/usaha yang akan dilaksanakan. Apalagi jika menyangkut kemaslahatan umat manusia.

Diperkuat dengan investor/pelaku usaha yang ketika dilakukannya konsultasi publik tidak menjelaskan secara detail terkait kegiatan/usahanya. Para investor/ pelaku usaha akan menjelaskan yang hanya menyangkut keuntungannya saja sedangkan untuk dampak potensial yang akan terjadi jarang dijelaskan ke masyarakat, meskipun terkadang dijelaskan dampak dan penanganan dampaknya belum tentu sesuai dengan kondisi lingkungan. Apabila wakil masyarakat dalam anggota Komisi Penilai AMDAL kurang sependapat atau pun di dokumen penyusun AMDAL masih belum lengkap atau dinyatakaan perlu diperbaiki maka Komisi Penilai AMDAL akan mengembalikan dokumen tersebut kepada investor/pelaku usaha untuk diperbaiki. Waktu yang dibutuhkan untuk menilai susunan AMDAL paling lama 75 hari kerja sejak dokumen KA dinyatakan lengkap. Apabila dokumen AMDAL telah lengkap maka menuju RKLRPL.

Tahap penyusunan RKL-RPL sama dengan menyusun dokumen AMDAL. Akan tetapi di tahap ini dokumen RKL memuat tentang upaya untuk mencegah, mengendalikan, dan menanggulangi dampak penting lingkungan hidup yang bersifat negatif dari suatu rencana kegiatan/usaha. Upaya-upaya dirumuskan berdasarkan hasil arahan dari dokumen AMDAL. Sedangkan untuk tahap RPL yakni dokumen disusun untuk memuat program-program pemantauan guna melihat perubahan yang terjadi akibat dampak dari pengaruh rencana kegiatan/usaha tersebut, memeriksa ketaatan investor/pelaku usaha terhadap peraturan lingkungan hidup dalam melaksanakan rencana kegiatan/usaha, dan juga dapat digunakan untuk menilai ketepatan perkiraan dampak yang digunakan dalam amatan AMDAL. Untuk proses penyusunan RKL-RPL apabila telah selesai dan tidak ada perbaikan, maka dokumen RKL-RPL dinilai terakhir oleh Komisi Penilai AMDAL.

Hasil penilaian akhir berupa saran kepada pejabat pemerintah yang berwenang. Kemudian pejabat tersebut menetapkan keputusan layak/tidaknya lingkungan hidup untuk digunakan sebagai rencana kegiatan/usaha. Dikeluarkannya keputusan kelayakan bila semua prosedur telah dipenuhi oleh investor/pelaku usaha dan harus mencantumkan jumlah dan jenis izin perlindungan dan pengelolaan lingkungan hidup sesuai dengan Pasal 33 ayat (2) Peraturan Pemerintah Nomor 27 Tahun 2012 tentang Izin Lingkungan. Sedangkan dikeluarkannya keputusan ketidaklayakan lingkungan minimal berisi dasar pandangan dikeluarkannya pernyataan dan penetapan ketidaklayakan lingkungan. Hasil keputusan kelayakan lingkungan hidup dilihat dan dicermati kembali, adakah keterlibatan masyarakat dalam proses penyusunannya hingga terakhir? Apabila masih belum ada keterlibatan masyarakat sepenuhnya maka 
dokumen AMDAL harus diuji kembali karena mengakibatkan AMDAL menjadi cacat hukum.

Pengujian kembali dokumen AMDAL yang cacat hukum jika menggunakan teori demokrasi deliberatif dapat melalui proses pemberian alasan atas suatu kebijakan publik di uji terlebih dahulu lewat konsultasi publik atau diskursus publik. Maksudnya pengujian dokumen AMDAL yang tidak melibatkan masyarakat dapat di uji kembali melalui konsultasi publik antara masyarakat, pemerintah yang berwenang, dan investor/pelaku usaha. Hal tersebut dikarenakan gagasan dari teori demokrasi deliberatif adalah sebagai jembatan jalan komunitas politik antara legislatif, eksekutif, yudikatif dalam hal ini yaitu pemerintah yang berwenang dengan masyarakat dan investor/pelaku usaha.

Dengan demikian, keterlibatan masyarakat dalam proses penyusunan AMDAL menurut regulasi yang berlaku telah dilindungi dengan jaminan hak-haknya untuk turut serta dalam proses penyusunan AMDAL tapi masyarakat yang belum dilibatkan masih belum sepenuhnya mendapatkan jaminan perlindungan di regulasi.

\section{B. Akibat Hukum dari Tidak Dilibatkannya Masyarakat dalam Proses \\ Penyusunan AMDAL}

Tidak adanya keterlibatan masyarakat hanya dianggap sebagai formalitas belaka menyebabkan dokumen AMDAL perlu dikaji ulang, karena pada dasarnya secara yuridis keterlibatan masyarakat dalam proses penyusunan AMDAL telah diatur dalam regulasi. Akan tetapi, tidak semua daerah memiliki peraturan daerah yang mengakomodir terkait keterlibatan masyarakat dalam penyusunan AMDAL seperti contoh di Kabupaten Jember. Namun, secara yuridis normatif tidak diikutsertakannya masyarakat dalam proses penyusunan AMDAL tidak berakibat hukum bagi dokumen AMDAL dikarenakan ketidakikutsertaan masyarakat dalam proses penyusunan AMDAL masih belum ada kejelasan di setiap regulasi.

Akibat kurang lengkapnya dokumen AMDAL dapat berupa kegiatan/usaha yang telah dilaksanakan sebelum kegiatan/usaha selesai harus terhenti, menyebabkan kegiatan/usaha menjadi tidak terurus meskipun kegiatan/usaha tersebut bermanfaat. Sebagai contoh dalam kasus reklamasi teluk Jakarta. Menurut penulis reklamasi teluk Jakarta sangat bagus bagi masyarakat mendatang tetapi karena masyarakat belum diikutsertakan pada waktu itu sehingga reklamasi teluk Jakarta harus dihentikan untuk sementara. Penghentian sementara terkait reklamasi teluk Jakarta dilakukan oleh pihak pemerintah dalam hal ini adalah Kementerian Lingkungan Hidup dan Kehutanan RI dan Kementerian Kelautan dan Perikanan.

Akibat lain dari tidak diikutsertakannya masyarakat dalam penyusunan dokumen AMDAL yakni mengakibatkan pencemaran atau kerusakan lingkungan, seperti kasus AMDAL PT. MSM/ PT TTN, provinsi Sulawesi Utara yang memiliki banyak hambatan. ${ }^{33}$ Dalam kasus tersebut dapat dicermati bahwa PT. MSM/ PT TTN telah kadaluwarsa dalam penggunaan AMDALnya sehingga harus mengajukan

Masrudi Muchtar, dkk, supra note 20 hlm. 92-95. 
perbaikan AMDAL. ${ }^{34}$ Ditambah dengan polemik di masyarakat bahwa telah terjadi pencemaran teluk Buyat sehingga menyebabkan sikap Gubernur Sulawesi Utara yang menyatakan kegiatan/usaha tersebut layak menjadi kegiatan/usaha tersebut harus dikaji ulang. Selain itu, meskipun PT. MSM/PT TTN telah membuat AMDAL lagi tapi menteri Lingkungan Hidup tidak mengeluarkan SK kelayakan AMDAL dengan alasan tidak berdasarkan pada peraturan perundang-undangan. ${ }^{35}$ Akibat-akibat lain dari tidak dilibatkannya masyarakat masih banyak karena sebenarnya masyarakat yang mengetahui kondisi dan situasi lingkungan sekitar, khususnya kondisi wilayah rencana kegiatan/usaha tersebut.

Sebenarnya jika tidak diikutsertakannya masyarakat dalam proses penyusunan AMDAL tidak berakibat hukum tetapi masyarakat kehilangan hak-haknya dan juga cacat prosedural. Selain itu, peran serta masyarakat untuk berpartisipasi dalam menyusun dokumen AMDAL diperkuat dengan asas partisipatif yang inti dari asas tersebut dapat dimaknai bahwa masyarakat di minta untuk turut aktif dalam proses pengambilan keputusan dan pelaksanaan perlindungan, serta pengelolaan lingkungan hidup yang baik dan sehat.

Hak-hak masyarakat diikutsertakan dalam menyusun dokumen AMDAL jika dimasukkan ke macam-macam hak, maka termasuk kedalam hak dasar sosial. Hak dasar sosial disini seperti hak atas lingkungan hidup yang layak dengan cara ikut berperan aktif dalam melindungi dan mengelola lingkungan hidup. ${ }^{36}$ Melihat dari hakhak yang dimiliki oleh masyarakat dalam keterlibatannya menyusun dokumen AMDAL dipertegas dengan asas partisipatif jika dijalankan dengan benar maka akan menghasilkan dokumen AMDAL yang sempurna. Berdasarkan hak-hak dan asas partisipatif yang telah dijelaskan di atas, masyarakat yang dilibatkan dalam menyusun dokumen AMDAL sesuai dengan prosedur penyusunan AMDAL dapat melalui penyampaian SPT, konsultasi publik hingga menjadi anggota komisi penilai AMDAL dimana harus adanya keterbukaan, efektivitas, pertanggungjawaban, dan berkualitas dalam melakukan pelaksanaan proses penyusunan AMDAL.

Keterbukaan disini merupakan keterbukaaan dalam memberikan informasi dan keterangan terkait rencana kegiatan/usaha. Selain pelaku usaha/investor juga memiliki kewajiban sebagaimana terdapat dalam Pasal 68 UUPPLH yang menyatakan bahwa "setiap orang yang melakukan usaha dan/atau kegiatan berkewajiban untuk memberikan informasi yang terkait dengan perlindungann dan pengelolaan lingkungan hidup secara benar, akurat, terbuka, dan tepat waktu, menjaga keberlanjutan fungsi lingkungan hidup; dan menaati ketentuan tentang baku mutu lingkungan hidup dan/ataau kriteria baku kerusakan lingkungan hidup."

Kewajiban tersebut harus dilaksanakan dengan baik oleh investor/pelaku usaha. Sehingga apabila hak-hak masyarakat tidak didapat dalam penyusunan dokumen AMDAL, dengan kata lain masyarakat tidak dilibatkan dalam proses penyusunan

34 Ibid.

35 Ibid.

36 Peter Mahmud Marzuki, Penelitian Hukum. Cetakan Keduabelas (Jakarta: Prenada Media Group, 2016) hlm. 142. 
AMDAL maka terjadi ketimpangan hukum, dikarenakan telah jelas dalam produk hukumnya bahwa masyarakat wajib ikut serta dalam proses penyusunan dokumen AMDAL.

Berdasarkan dari implementasinya yang pernah dilakukan oleh penulis melalui wawancara kepada masyarakat yang akan terkena dampak di pantai Paseban berbeda dengan substansi dari regulai lingkungan hidup. Penulis melakukan wawancara ketika terjadi konflik pertambangan di Jember, khususnya di pantai Paseban satu tahun yang lalu bahwa disana keterlibatan masyarakat sangat minim, Penyebabnya mayoritas masyarakat tidak setuju jika pertambangan dilakukan karena dapat menyebabkan erosi dan tsunami. Tetapi investor/pelaku usaha tidak menjelaskan dengan baik. Meskipun telah mengetahui mayoritas masyarakat tidak setuju tetapi PLT bupati Jember tetap meyetujui akan adanya pertambangan. Sehingga di Paseban masyarakat tidak mendapatkan haknya dengan baik khususnya tidak adanya transparansi dalam pemberian informasi. Ditambah dengan tidak adanya peraturan daerah maupun surat keputusan dari bupati lokasi mana yang dapat dilakukan rencana/kegiatan usaha yang wajib AMDAL.

Meskipun telah dilakukan pemetaan dalam tata ruang dan wilayah Kabupaten Jember tetapi tetap tidak digunakan sebagai acuan diizinkan atau tidaknya rencana kegiatan/usaha tersebut. Berdasarkan dari wawancara tersebut penulis mengambil benang merahnya bahwa tidak adanya keterlibatan masyarakat dalam menyusun dokumen AMDAL masih belum ada tindak lanjut maupun sanksi terkait kepastian hukum, oleh karenanya perlu diatur lebih lanjut. Hal tersebut dapat dilihat bahwa hanya sanksi terkait pelanggaran izin lingkungan saja sedangkan untuk lebih khusus mengatur tentang pelanggaran sanksi dari pelaksanaan prosedur penyusunan AMDAL yang tidak melibatkan masyarakat masih belum ada.

Jika dicermati ke dalam UUPPLH terkait sanksi administratif yang diatur dalam Pasal 76 maupun sanksi pidana dalam Pasal 109-112 belum ada yang mengatur tentang pelanggaran sanksi dari pelaksanaan menyusun dokumen AMDAL yang tidak melibatkan masyarakat. Pasal 109-112 hanya memberlakukan asas premium remedium karena sanksi yang diberikan lebih ringan dari batas maksimum KUHP. Oleh karenanya mengakibatkan penegakan pidananya menjadi tidak jelas, terkhusus pada pemberian putusan sebagai upaya efek jera bagi pelaku.

Ketika undang-undang, peraturan pemerintah, peraturan daerah maupun surat keputusan dari bupati/walikota tidak mengatur tentang perlindungan dari tidak dilibatkannya masyarakat dalam proses penyusunan AMDAL mengakibatkan masyarakat tidak memiliki payung hukum maupun jaminan hukum untuk menuntut haknya. Oleh sebab itu, perlu adanya perbaikan instrumen hukum yang berkaitan dengan konsekuensi ataupun sanksi bagi investor/pelaku usaha yang tidak melibatkan masyarakat dalam proses penyusunan dokumen AMDAL, dengan melakukan revisi UUPPLH terkait substansi dari penyusunan dokumen AMDAL yang tidak melibatkan masyarakat, dan menambah substansi sanksi bagi investor/pelaku usaha yang tidak melibatkan masyarakat dalam menyusun dokumen AMDAL. 
Sesungguhnya tidak hanya regulasi saja yang harus diubah ataupun diperbaiki tapi pihak yang penulis kritik dalam hal ini yaitu pelaku usaha/investor dan pemerintah yang berwenang (menteri, gubernur, maupun bupati/walikota) harus menjalankan tugas dan tanggungjawabnya seperti yang telah diamanatkan dalam regulasi. Investor/pelaku usaha harus melibatkan masyarakat dalam proses penyusunan AMDAL serta memberikan informasi yang transparan dan mudah di mengerti oleh masyarakat sekitar, khususnya masyarakat yang terkena dampak, selain itu investor/pelaku usaha harus mentaati setiap prosedur penyusunan AMDAL. Sedangkan untuk pihak pemerintah yang berwenang (menteri, gubernur, maupun bupati/walikota) harus mengawasi dan menjalankan pertanggung-jawabannya sesuai dengan peraturan perundang-undangan, khususnya tentang pemberitahuan informasi kepada masyarakat.

Pasal 62 UUPPLH yang menyatakan bahwa ayat (1) Pemerintah dan pemerintah daerah mengembangkan sistem informasi lingkungan hidup untuk mendukung pelaksanaan dan pengembangan kebijakan perlindungan dan pengelolaan lingkungan hidup; ayat (2) Sistem informasi lingkungan hidup dilakukan secara terpadu dan terkoordinasi dan wajib dipublikasikan kepada masyarakat; dan (3) Sistem informasi lingkungan hidup paling sedikit memuat informasi mengenai status lingkungan hidup, peta rawan lingkungan, dan informasi lingkungan hidup.

Dari pernyataan pasal tersebut dapat diartikan bahwa pemerinah yang berwenang harus menginformasikan kepada masyarakat tentang kegiatan/usaha yang akan dilakukan. Apabila menteri, gubernur, bupati/walikota tidak memberikan informasi secara lengkap ataupun tidak melakukan pengawasan terhadap rencana kegiatan/usaha dan investor/ pelaku usaha juga tidak menjalankan prosedur sesuai dengan peraturan yang ada maka dapat berakibat hukum.

Tidak dilibatkannya masyarakat dalam proses penyusunan AMDAL juga merupakan sebuah peristiwa hukum yang seharusnya memiliki akibat hukum tertentu. Banyak orang berpendapat bahwa akibat hukum merupakan sebuah akibat yang diatur oleh hukum atas suatu peristiwa, tetapi jika dicermati lebih mendalam banyak peristiwa hukum yang menimbulkan akibat, namun secara yuridis normatif tidak diatur dalam regulasi yang jelas. Peristiwa tidak dilibatkannya masyarakat dalam proses penyusunan AMDAL salah satunya.

Oleh sebab itu, dikarenakan proses penyusunan AMDAL yang tidak melibatkan masyarakat termasuk dalam sebuah peristiwa hukum yang seharusnya berakibat hukum, maka masyarakat yang tidak dilibatkan dapat mengajukan permohonan pembatalan ataupun perubahan AMDAL yang telah disetujui ke PTUN. Dimana nantinya majelis hakim lah yang akan meminta investor/pelaku usaha untuk mengubah AMDALnya dan meminta pemerintah yang berwenang untuk melakukan pembatalan dan memerintahkan investor/pelaku usaha untuk mengkaji ulang AMDAL yang telah disetujui. Selain itu, dokumen AMDAL yang telah selesai tersebut harus diperbaiki kembali dengan melihat dari tahap mana pelaku usaha/investor tidak menjalankan prosedur terkait melibatkan masyarakat dalam proses penyusunan dokumen AMDAL. 
Apabila masyarakat tidak dilibatkan sejak awal maka investor/pelaku usaha harus mengkaji ulang mulai awal rencana/kegiatan tersebut. Namun, jika sampai SPT atau komisi AMDAL maka perbaikan AMDAL mulai dari SPT atau komisi AMDAL. Tetapi juga perlu dilihat penyebab dokumen AMDAL sebelumnya dalam rencana kegiatan/usaha tersebut dapat lolos dari prosedur penyusunan AMDAL.

\section{KESIMPULAN}

Perlindungan hukum tentang keterlibatan masyarakat dalam proses penyusunan AMDAL menurut peraturan perundang-undangan yang berlaku telah dijamin hakhaknya tapi masih belum ada jaminan perlindungan bagi masyarakat yang tidak dilibatkan dalam proses penyusunan AMDAL, bahkan implikasi dari peraturan perundang-undangan tersebut masih minim dan tidak dilibatkannya masyarakat dalam proses penyusunan AMDAL berimplikasi pada dapat diajukannya gugatan ke PTUN dan investor/pelaku usaha berkewajiban untuk memperbaiki dokumen AMDAL mulai tahap investor/pelaku usaha tidak melibatkan masyarakat dalam proses penyusunan AMDAL.

Pemenuhan hak dari masyarakat yang tidak dilibatkan dalam proses penyusunan AMDAL dapat dengan menambah substansi dari Peraturan Pemerintah Nomor 27 Tahun 2012 tentang Izin Lingkungan, dengan memberikan sanksi yang tegas bagi pelaku usaha/investor maupun bagi pemerintah yang berwenang apabila tidak mengikutsertakan masyarakat dalam proses penyusunan AMDAL dan mengubah substansi pasal 9 ayat (4) untuk kembali mengacu pada peraturan lama terkait jangka waktu yang diberikan kepada masyarakat.

Perlu dilakukan perubahan terhadap substansi dari Peraturan Menteri Lingkungan Hidup Nomor 17 Tahun 2012 tentang Pedoman Keterlibatan Masyarakat Dalam Proses Analisis Dampak Lingkungan Hidup dan Izin Lingkungan, yakni menambah substansi norma yang berkaitan dengan perlindungan masyarakat yang tidak diikutsertakan dalam proses penyusunan AMDAL, khususnya masyarakat yang terkena dampak, dan adanya instruksi dari pemerintah pusat untuk wajib dibuatkannya peraturan daerah tentang kewajiban pelaku usaha/investor untuk melibatkan masyarakat dalam proses penyusunan AMDAL di setiap kabupaten/kota yang substansinya memuat tentang konsekuensi bagi pelaku usaha yang tidak melibatkan masyarakat dalam proses penyusunan AMDAL.

\section{DAFTAR PUSTAKA}

Andi Hamzah, Penegakan Hukum Lingkungan ( Jakarta: Sinar Grafika, 2000).

St. Munadjat Danusaputro, Hukum Lingkungan Buku I: Umum (Bandung: Binacipta, 1985).

A'an Efendi, Hukum Lingkungan Instrumen Ekonomik dan Pengelolaan Lingkungan di Indonesia dan Perbandingan dengan Beberapa Negara (Bandung: PT Citra Aditya Bakti, 2014). 
Antun Mardiyanta, "Kebijakan Publik Deliberatif: Relevansi dan Tantangan Implementasinya" (2011) 24:3 J Univ Airlangga.

BPK.go.id, "BPK beberkan empat tahap penyimpangan" http://www.bpk.go.id/ news/bpk-beberkan-empat-tahap-penyimpangan diakses pada Rabu, 14 Juni 2017, pukul 10.09 WIB.

Daud Silalahi dan Kristanto, Perkembangan Pengaturan AMDAL di Indonesia, (Bandung: Keni Media, 2016).

F. Gunawan Suratmo, Analisis Mengenai Dampak Lingkungan, (Yogyakarta: Gadjah Mada University Pers, 2009).

Forbali.org, " Pernyataan sikap tolak reklamasi berkedok revitalisasi teluk benoa “ http://www.forbali.org/id/pernyataan-sikap-tolak-reklamasi-berkedokrevitalisasi-teluk-benoa/, di akses pada Rabu, 14 Juni 2017, pukul 08.40 WIB.

Helmi, Hukum Perizinan Lingkungan Hidup (Jakarta: Sinar Grafika,2012).

Masrudi Muchtar, Hukum Keschatan Lingkungan (Kajian Teoritis dan Perkembangan Pemikiran) (Yogyakarta: Pustaka Baru Press, 2016).

Masri, R.M, “Evaluasi AMDAL Pembangunan Gedung 10 Lantai Di Pusat Kota Bandung” (2016) Jur UMM.

Mohammad Taufik Makarao, Aspek-Aspek Hukum Lingkungan (Jakarta: PT Ikrar Mandiriabadi, 2006).

Mongabay.co.id, "Tanpa Perda Zonasi sudah terbitkan pergub reklamasi" http://www.mongabay.co.id/2017/01/17/tanpa-perda-zonasi-ahok-ternyatasudah-terbitkan-pergub-reklamasi/. Di akses pada Rabu, 14 Juni 2017, pukul 08.00 WIB.

N.H.T. Siahaan, Hukum Lingkungan dan Ekologi Pembangunan, Cetakan Kedua (Jakarta: Erlangga, 2004).

Pan Mohamad Faiz, "Perlindungan terhadap Lingkunngan dalam Perspektif Konstitusi" (2016)13:4 J Konstitusi.

Peter Mahmud Marzuki, Penelitian Hukum. Cetakan Keduabelas, ( Jakarta: Prenada Media Group, 2016).

Sudharto P. Hadi, Aspek-Aspek AMDAL Sejarah, Teori dan Metode, Cetakan Keempat. (Yogyakarta: Gadjah Mada University Pers, 2005).

T. Gayus Lumbun, Hukum Dan Lingkungan Hidup Di Indonesia (Jakarta: Program Pasca Sarjana Fakultas Hukum Universitas Indonesia, 2001).

Tempo, "Tolak PLTU Warga Satu Kelurahan di Bengkulu Minta Direlokasi" https://m.tempo.co/read/news/2016/09/02/173801157/tolak-pltu-warga-satukelurahan-di-bengkulu-minta-direlokasi. Di akses pada Rabu, 14 Juni 2017, pukul 09.42 WIB. 